THE AMERICAS 66:4/April 2010/469-499 COPYRIGHT BY THE ACADEMY OF AMERICAN FRANCISCAN HISTORY

\title{
BataClanismo! Or, How Female Deco Bodies Transformed Postrevolutionary Mexico City
}

I n the spring of 1925, Santa Anita's Festival of Flowers seemed to follow its tranquil trend of previous years. The large displays of flowers, the selection of indias bonitas (as the contestants of beauty pageants organized in an attempt to stimulate indigenism were known) and the boat-rides on the Viga Canal, all communicated what residents of neighboring Mexico City had come to expect of the small pueblo in the Federal District since the Porfiriato: the respite of a peaceful pastoral, the link to a colorful past, and the promise that mexicanidad was alive

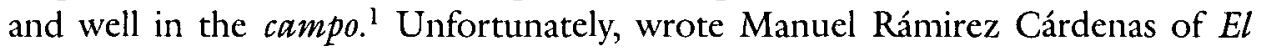
Globo, "the modern newspaper," the next day, this idyllic tradition was rudely interrupted by a group of audacious, scantily clad women. The culprits were actresses of Mexico City's Lírico theater, who walked around Santa Anita's streets in "picaresque clothing"-stage outfits that left little to the imagination, particularly in broad daylight-and upset visitors and campesinos alike. According to Cárdenas, abuelitas and mamás were shocked by the display, averting their eyes from the female spectacle in fear of "el pecado mortal." Thankfully, for the mothers and grandmothers in the audience, the festival continued in predictable fashion after the initial uproar. Organizers continued with the traditional dances, and judges selected an india bonita from a pool of young, decente mestizo girls to represent the pueblo and the festival.

Unbeknownst to the residents of rural Santa Anita, the daring actresses of El Lírico were part of a new phenomenon that had swept through Mexico City like

This article has benefitted from comments and suggestions by a number of generous readers. Specifically, I would like to thank Elise Edwards, Anne Rubenstein, Eric Zolov, and the anonymous reviewers of The Americas.

1. Micheal Johns, The City of Mexico in the Age of Diaz (Austin: University of Texas Press, 1997), p. 38. For a discussion on the India bonita beauty contests, see Rick A. López, "The India Bonita Contest of 1921 and the Ethnicization of Mexican National Culture," Hispanic American Historical Review 82:2 (2002), pp. 291+328. López traces the first India Bonita contest to 1921 and argues that these pageants in which an "Indian girl" was elected, sought to inculcate a national identity based on the idea that all Mexicans shared as well as should honor their indigenous past.

2. Manuel Rámirez Cárdenas, "Santa Anita; colores y flores, El modernismo impera ya en la tradicional fiesta, Hubo Rataplan en pleno canal de la Viga," El Globo, April 4, 1925, p. l. 
wildfire, turned the entertainment world upside down, and pushed many to reconsider what constituted female beauty, decency, and lo mexicano. A few months earlier, on February 12th, a grand variety spectacle named Voilá Paris: La Ba-ta-clán premiered in Teatro Iris and instantly sent shock waves throughout the Mexican entertainment world and the larger metropolis. The show featured seminude and nude French actresses, who performed dances and acts that appeared to be a mix of classical ballet, Ziegfeld Follies chorus lines, and tableaux vivants. Within weeks, Mexican copycat productions capitalized on the enormous success of the show, triggering a new entertainment phenomenon named after the original production: Bataclanismo. It also launched a new kind of female star, the bataclana, who came to represent the erotic, and more dangerous, attributes of the flapper for Mexican audiences, and whose body became the site of contested and divergent notions of modernity.

In this article, I explore bataclanismo as a normative discourse that reached far beyond the theater into the practice of everyday life. I do so to gauge the transition of changing ideals of femininity in Mexico from 1925 to 1935, and the influence these changes had on the development of urban space. Drawing on Elizabeth Grosz' and Doreen Massey's insights that place and gender are mutually constitutive, this article examines the articulation between the embodied city and changing gender norms in the wake of both the Mexican revolution and the advent of twentieth-century global capital. ${ }^{3}$ Analyzing these relationships from Judith Butler's perspective of gender performance, especially as read through bodies, ${ }^{4} \mathrm{I}$ argue that a new transnational aesthetic of feminine embodiment celebrated in bataclanismo influenced a distinct urban modernity and sociability in Mexico City. This new ideal female physique that stressed length, height, and androgyny - what I term a Deco body-helped to reconfigure Mexico City in terms of gender, space and race. It ushered in new gender ideals, helped visualize urban modernity, and bridged the gap between two divergent discourses that accompanied revolutionary reform, indigenismo and mestizaje, paving the way for a "mestizo modernity."

\section{BATACLANISMO!}

During and after the armed phase of the Mexican revolution (1910-1920), which claimed nearly 2 million lives and displaced many more, the majority of migrants

3. Elizabeth Grosz, "City-Bodies" in Space, Time, Perversions: Essays on Politics of the Body (London: Routledge, 1995); Doreen Massey, Place, Space and Gender (Minneapolis: University of Minnesota Press, 1994), p. 179.

4. See Judith Butler, Gender Trouble: Feminism and the Subversion of Identity (New York City: Routledge, 1990), and Bodies That Matter: On the Discursive Limits of ${ }^{\alpha} S e x^{\supset}$ (New York City: Routledge, 1993).

5. I borrow the term from Tace Hedrick, Mestizo Modernism: Race, Nation and Identity in Latin American Culture, 1900-1940 (Newark: Rutgers University Press, 2004). 
who reached Mexico City were women who hoped to escape the ravages of war in the countryside, or sought refuge after losing male protection after the death of husbands, fathers, and brothers. ${ }^{6}$ Women fled to Mexico City as it was spared the devastation and violence that typified the revolution in the countryside. Most of the poorer migrants settled in crowded Porfirian vecindades (slums) or in viviendas (tenements) in the city center. Many lower-class women survived as beggars, factory workers, and as servants for the remainder of Porfirian middle-class society and the emerging revolutionary elite. ${ }^{7}$ For disadvantaged women, the informal economy-street vending, domestic service, and prostitution-formed the only means of survival. Concern over women in public places, whether prostitutes or not, resonated strongly throughout the postrevolutionary period as leaders linked nation building with family reform. Moreover, state anxieties over "free women" and their contribution to the disintegration of society mounted during the 1920s and 1930s with the proliferation of women's activism in the wake of the revolution and the arrival of the so-called New Woman, as exemplified by the North-American flapper.

On the global stage, the ideal of the New Woman emerged in the post-World War I era, a period that facilitated women's claims to new forms of both political and social mobility. This ideology was articulated through a radically different idea of femininity that postulated a new way of discerning physical beauty. The Deco body marked a shift from the nineteenth-century aesthetic embodied by the theater diva to the new beauty ideal characterized by movie stars. The voluptuous hourglass figure of the Victorian era (enhanced by restrictive corsets) gave way to the long, sleek physique of well-toned female bodies still celebrated today as the reigning beauty ideal. Lucy Fischer suggests that Art Deco "compressed," "streamlined" and reduced the complexity of women's corporeality. Although the female form featured heavily in Art Deco, it represented the female body as a silhouette, a mere outline. ${ }^{8}$

6. Katherine E. Bliss, Compromised Positions: Prostitution, Public Health, and Gender Politics in Revolutionary Mexico City (University Park: Pennsylvania State University Press, 2002), p. 73. For recent reassessment of the demographic collapse duc to the Revolution, sce Robert McCaa, "Missing Millions: The Demographic Costs of the Mexican Revolution," Mexican Studies/Estudios Mexicanos 19:2 (2003), pp. 367-400. While McCaa's main argument centers on the demographic toll due to the so-called multiplier factor where potential reproduction rates based on pre-revolutionary population figures and birthrates is taken into account, he also notes that the actual death toll during the revolution is estimated to be 1.9 to 3.5 million. See also Robert McCaa, "Missing Millions: the Human Cost of the Mexican Revolution," http://www.hist.umn.edu/ -rmccaa/missmill/mxrev.htm, accessed January 10, 2010.

7. Jonathan Kandell, La Capital: The Biography of Mexico City (New York City: Random House, 1988), p. 448; Susie P. Porter, "'And That Is Custom Makes It Law': Class Conflict and Gender Ideology in the Public Sphere, 18801910," Social Science History 24:1 (2000), p. 129. Porter states that during the years spanning from 1880-1921, the majority of migrants to Mexico City were women. Pablo Piccato estimates that women made up more than 55 percent of all the inhabitants of Mexico City by 1930. Pablo Piccato, City of Suspects: Crime in Mexico City, 1900-1931 (Durham: Duke University Press, 2001), p. 22.

8. Lucy Fischer, Designing Women: Cinema, Art Deco and the Female Form (New York City: Columbia University Press, 2003), p. 32. 
While the appearance of the Deco body was a transnational phenomenon that had originated in Europe and the United States in the wake of the First World War, bataclanismo functioned locally as a catalyst transforming the idea of female beauty and cosmopolitan living in Mexico. In 1925, Esperanza Iris introduced the capital city and the nation to this new beauty ideal by contracting a performance by the Parisian company of Madame Rasimi for her theater. Iris, a celebrity from the Porfirian era who enjoyed a long career as an opera star, actress, agent and theater owner, first stepped onto the stage in the role of a newspaper boy in 1899 . At that time Mexico City counted a mere 350,000 inhabitants and resembled a large provincial town instead of a large bustling metropolis, which its increasingly misplaced nickname, "The City of Palaces," suggested. By the end of the armed phase of the revolution, Iris had come to embody the female aesthetic of a classic European diva: opulence, grace, and coy sexuality. Iris also had grown into a shrewd businesswoman, and used her earnings to build a state-of-the-art theater. Upon its opening in 1918, she envisioned her theater would function as a venue to bring "novelties, art, and luxury" to Mexico City. ${ }^{9}$ Her greatest theatrical accomplishment in that sense was her decision to contract the Parisian company of Berthe Rasimi, forever altering the theatrical landscape of the Mexican stage as well as that of the city.

With the aptly titled show Voilá Paris, Iris and Rasimi, both older women of nineteenth-century fame, brought the latest fashions and ideas of a new, brazen and highly sexual femininity to Mexico. Many women in Mexico City would use the Bataclán and its Deco bodies to contest the revalorization of male authority that typified revolutionary reform. The new Deco body was not merely another new European fashion ideal easily read as a remnant of Porfirian cultural sensibilities, but rather it allowed capitalinas to claim sexual liberty and increase their physical mobility in a highly provincial and class-stratified city. In doing so, they ran up against new political elites and their ideas of revolutionary womanhood, even if these elites (reformers from the outward-looking northern state of Sonora) also hoped for a more metropolitan Mexico City that could join the ranks of Paris, Berlin, or New York City.

Before arriving in Mexico, the Bataclán had enjoyed great success in Europe, as well as Brazil and Argentina. Madame Rasimi, a great entrepreneur and owner of the Ba-ta-clán Vaudeville Theater in the Bastille quarter of Paris, took the ensemble on a South American tour in 1922, where the show at first garnered mixed reactions. The Brazilian press, for instance, was initially far from supportive. The day before the Bataclán was to premiere in Rio de Janeiro, the press reported that diplomats who had seen the spectacle in Paris felt the show contained scenes insult-

9. Araceli Rico, El Teatro Esperanza Iris: La pasión por las tablas (Mexico City: Plaza y Valdés, 1999), p. 66. 
ing to the Brazilian national character. Despite the criticism, however, the Bataclán was a great success with the cariocas. Rasimi staged four successive Bataclán revues at Rio's Teatro Lírico: Paris Chic, Pour Vous Plaire, Voila Paris, and Au Revoir. ${ }^{10}$

The show proved enormously popular with Mexican audiences as well. Adapted in part from Darius Milhaud's ballet Le Boeuf, the Bataclán consisted of an array of dance acts without a single unifying theme, performed by lanky, scantily dressed Parisian girls, culminating in a grand spectacle of female flesh that eclipsed anything earlier divas had dared to exhibit. The central theme of seductive, female beauty was certainly not new to Mexican theater, but the Bataclán was an innovative production in terms of the spatial relationship of actresses and audience visà-vis the stage, the lack of a discernable narrative, and the degree of actual nudity. ${ }^{11}$ Most importantly, it marked a shift away from a single female star. Instead, a line of chorus girls paraded their bodies with choreographed uniformity that, in many ways, foreshadowed Busby Berkeley's films of the 1930s as well as today's fashion shows. With its incredible success, the Bataclán quickly metamorphosed into a phenomenon, bataclanismo, one which would alter how many Mexican men and women came to understand feminine behavior.

Not surprisingly, Voilá París caused quite some controversy-increasingly a crucial ingredient for successful shows. Critics were divided and debated its validity and meaning. Repeatedly advertised and labeled as "the newest spectacle," the Bataclán was destined to upset old customs and shock provincial morals. Some critics questioned the virtuousness of the eight dancers, described as "living Greek columns" proudly displaying their naked bodies adorned only with some exotic feathers. Other members of the press, however, expressed ebullient admiration. As one theater critic remarked:

As if they were golden heralds of spring, the pretty little French girls have made our Valley erupt. The sinful happiness of Montmatre has stretched over the metropolis like a radiant fire. The burden of our ancestral melancholy has become lighter, only at hearing their boulevardesque laughter. We marvel at the Venusian parade of the modern goddesses of Paris, who move about the stage as living statues. ${ }^{12}$

If the dancers looked like goddesses, they certainly evoked human desires, and showed off their bodies in shameless fashion. ${ }^{13}$ Iris had struck gold. The triumph

10. Elizabeth Travassos and Manocl Aranha Corrêa do Lago, "Darius Milhaud e os compositores de tangos, maxixes, sambas e cateretês," Revista Brasileira 11:43 (April-May-June, 2005), cited by http://daniellathompson.com/ Texts/Le_Boeuf/boeuf.pt.15-16.htm, accessed February 3, 2010.

11. While carlier theater productions, especially revistas, had merely alluded to female nudity with actresses dressed in body stockings, the bataclanas performed "sans mallots," i.e., without the flesh-colored body stockings usually worn.

12. Passage cited in Antonio Zedillo Castillo, El Teatro de la Ciudad de Mexico Esperanza Iris: Lustros, lustres, experiencias y esperanzas (Mexico City: Socioculture D.D.F., 1989), p. 93.

13. Ibid. 
of Voila Paris inspired two more presentations by the ensemble within the same month: Cachez-Ca and $O b$ La La! The performances included fashion shows, where the dancers-cum-models got even closer to the public through the innovative use of catwalks.

Despite its apparent superficiality, the Bataclán revolutionized Mexican theater by infusing a new, overt female sexuality into the genre of the political revista that had become the mainstay of popular theater in the wake of the revolution. ${ }^{14}$ Mexico City's theater world quickly responded to the success of the Bataclán. Producer José Campillo's and actor Roberto Soto's satire, Voilá Mexique: El Rataplan, debuted in El Lírico just a month later, and became an instant classic. ${ }^{15}$ Thanks to fierce promotion that promised "neither an old one, nor an ugly one" in the cast of Mexican girls, it met with even greater success than its Parisian original. ${ }^{16}$ Some Mexican historians have explained Rataplan's success as a nationalistic impulse to demonstrate that Mexico refused to stay behind the European avant-garde and, as such, that it was indicative of the era's rather superficial exuberance. According to these scholars, the phenomenon was born of modern ennui and indifference, of excess and fraud, and of wanting to forget the hardships of the revolution. ${ }^{17}$ The Rataplan, however, did not consist of mere mimicry. Unlike its French counterpart, the work mixed female sexuality with political satire, and questioned social conditions in the city's poorest barrios, such as Tepito. Due to their association with sex and political scandal, these revistas, and their stars, remained profitable business material well into the 1930 s, as evidenced by biographies of famous bataclanas. ${ }^{18}$

Bataclanesque shows such as the Rataplan thus fused eroticized female nudity with social commentary, a combination that quickly became a common feature of Mexican revistas. Perhaps, as Kristin McCleary argued in the case of theater in 1920s Buenos Aires, theater in Latin America moved more and more towards the revista genre due to the ever-growing popularity of film, especially the allure

14. Revista theater was related to U.S. revues and French vaudeville, yet differed from these in its use of political satire. Attended mostly by a middle-class audience in more upscale theaters, the revista style was also favored in workingclass theaters and carpas, i.e., itinerant tent theaters. See Ageeth Sluis, "City of Spectacles: Gender Performance, Revolutionary Reform and the Creation of Public Space in Mexico City, 1915-1939" (Ph.D. dissertation, University of Arizona, 2006).

15. This is loosely translatable as Here is Mexico: The Rat Manifesto, as "plan" was frequently used in Mexico to outline political programs, especially during the revolution, i.e., Emiliano Zapata's Plan de Ayala.

16. Pablo Dueñas, Las divas en el teatro de revista mexicano (Mexico City: Asociación Mexicana de Estudios Fonográficos: Dirección General de Culturas Populares, 1994), p. 25.

17. Ariceli Rico suggests that bataclanismo fit the age's changing social climate of "indiscrete looks, parody, temptation between the stage and the public, the vacilón as life style, strong and seductive perfume, flight of husbands, red plumage and the cabaret as place of refuge." Rico, El Teatro Esperanza Iris, pp. 101-2.

18. For instance, the popular men's magazine Mujeres y Deportes reported that María Rivera, a one-time star of adult entertainment clubs in Plaza Garibaldi, "undressed her life" in her 1938 autobiography Frine criolla as she had her body on the stagc. "Una tiple cuenta su vida!," Mujeres y Deportes, February 12, 1938, p. 22. 
of Hollywood cinema. ${ }^{19}$ Above and beyond the theater's growing competition with the movies, however, revistas offered audiences an alternate way to navigate transnational modernity as well as messages emanating from the reform-minded revolutionary state. Revista nudity was deemed modern, and therefore was not censored. The fact that families attended revistas was considered the best proof that the genre consisted of "moral entertainment." Political content, on the other hand, was more likely to catch the attention of censors. Under the auspices of the Ayuntamiento (municipal government), censorship was most heavily leveled against the political revistas critical of the revolutionary leadership, such as "Don Adolfo's Orchard Sister Water," "National Bargain Sale," and "Obregón's Garden."20

Due to the influence of the Bataclán, the codified cast of revista theater, made up of nineteenth-century regional tipos that had evolved into stock urban characters, now mingled with naked, statuesque bodies, and positioned mexicanidad against the "exquisite feathers and delicious veils" of Parisian-like chorus girls. Even if this stark contrast signaled the general contradictions that marked Mexican society, the presence of Bataclanesque figures in revistas also suggested that Deco bodies represented a desirable femininity that could be integrated into a proudly nationalist society. ${ }^{21}$ Moreover, the Rataplan turned revista theater into a truly urban performance, rallying new energies in the face of the caudillo showmanship of national leaders. While bataclanismo might have offended middle-class sentiments in the "elite" Teatro Iris, the most upscale venue in the city, ${ }^{22}$ it quickly spread throughout theaters across the city, including in lower-class barrios. Carpas (tent theaters) frequented by the working-class also integrated bataclanismo into their larger repertoire of satire and social commentary. Lo Bataclanesco quickly became fashionable beyond its initial bourgeois audience, fueling a wave of theatrical works characterized by lack of clothing, including La fiebre del Ba-ta-clan (The Fever of the Bataclán) with María Conesa, ;No lo tapes! (Don't Cover It!), which saw the debut of Lupe Vélez as bataclanismo's first real star, and, eventually, Desnudos para familias (Nudes for Families). Teatro Iris also continued with profitable light spectacle, staging variety shows and piquant comedies such as U.S.-Follies performances, Kiss-me and Yes-Yes. The phenomenon did not cease until the latter half of the 1930s when bataclanismo gave way to pornographic burlesque, which flourished in lowbrow theatres such as Apolo and Tivoli. ${ }^{23}$

19. Kristen L. McCleary, "Culture and Commerce: An Urban History of Theater in Buenos Aires, 1880-1920" (Ph.D. dissertation, University of California at Los Angeles, 2002), p. 209.

20. Rodolfo Usigli, Mexico in the Theater (University: Romance Monographs, 1975), p. 123

21. Rico finds that the incongruities between the stock revista types and the imported chorus girls reflected the general contradictions in Mexican society. Rico, El Teatro Esperanza Iris, p. 106.

22. Zedillo Castillo, El Teatro de la Ciudad, p. 95.

23. Dueñas, Las divas, pp. 25-6. 
FIGURE 1

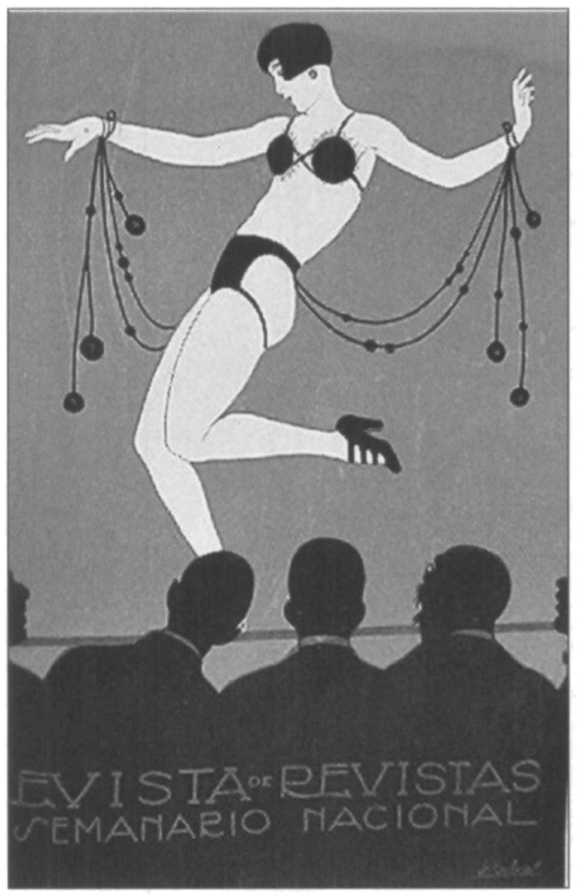

Figure 2

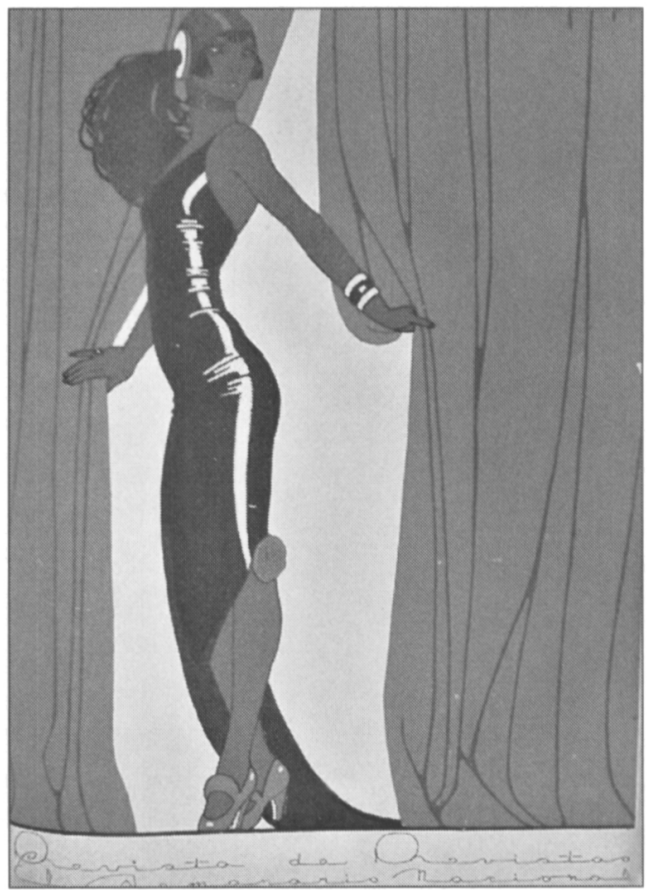

Source: Ernesto García Cabral, Revista de Revistas (cover art), February 15, 1925; July 4, 1926.

Not surprisingly, the more dancers revealed, the more public exposure they enjoyed. A barrage of bataclanesco imagery inundated Mexico City's press starting in 1925, ranging from refined aestheticization to sultry satire. The press informed the way female spectacle was to be seen and helped consolidate bataclanismo as a distinct discourse. It was this discourse, rather than the original show, that took the Deco body beyond its theatrical limits and promoted its performance as part of everyday metropolitan modernity. Above and beyond the photos of actresses that adorned newspapers, weeklies, and magazines, the drawings of artist and cartoonist Ernesto García Cabral captured Bataclán's Deco bodies to unparalleled perfection. ${ }^{24}$ His many covers for Revista de Revistas, the high circulation weekly owned by the national newspaper Excélsior, stood out in particular due to their innovation in style, lay-out, and color in an era of largely black-and-white imagery. He also connected the Deco bodies of the stage with

24. While Cabral is a well-known caricaturist in Mexico, whose career spanned many decades, little about him has been published in English-language publications. For a biographical article and analysis of his work, see Joanne and Randy Barrow and Fred Katz, "Ernesto Cabral: Mexican Poster Artist and Caricaturist," Comic Art 4 (2003), pp, 1431. For references to Cabral's later works, see Eric Zolov, "Jorge Carreño's Graphic Satire and the Politics of 'Presidentialism' in Mexico during the 1960s," Estudios Interdisciplinarios de América Latina y el Caribe 17:1 (2006), pp. 13-38. 
the New Women in the city by showing both as sophisticated, independent, and stylish. In many ways, these women, who appeared in many guises yet inhabited shared physiques and flaunted similar attitudes, were stand-ins for the modern metropolis. ${ }^{25}$ Through their color, their brazen style, and their Deco bodies, Cabral's women mapped the future of a new femininity onto the developing urbe.

Cabral, nicknamed el Chango (the monkey) because of his agility, was described by contemporaries as a bohemian, a non-conformist, and a genius. In his work, he connected an incipient Mexican metropolitanism to female bodies like no other Mexican visual artist of his time. Having come of age during the late Porfiriato, Cabral irreverently used his training at the famed Academy of San Carlos to draw political cartoons for weeklies, and quickly earned fame with his caustic caricatures. President Francisco Madero so feared the artist's work that he sent him off with a generous scholarship to study in Paris. Like Diego Rivera (and sometimes with Rivera) Cabral spent some of the most turbulent years of the revolution in Paris, living the bohemian life of the Quartier Latin. As the cultural attaché to the Mexican consulate, Cabral later traveled to Spain and Buenos Aires, where he remained until 1918. ${ }^{26}$ Rivera and José Clemente Orozco thought of him as the greatest sketch artist of their generation, while other contemporariesalways happy to nationalize greatness-praised him as a true Mexican artist due to his use of vibrant colors. So influential were Cabral's portadas (covers) that fashion designers eagerly awaited each issue of Revista de Revistas before designing new collections. According to a retrospective, Cabral "specialized in painting women ingénues and sophisticates who seemed to languish in a constant state of elegance." 27 If not languishing, Cabral always rendered the Deco bodies of the New Women as long and languid, confident and relaxed even when he placed them in the midst of a frenetic and exciting modern scene. While Cabral is best remembered in Mexico for his political caricatures, his art that outlined a new type of femininity was prolific and powerful. Even his unsigned movie posters from the 1940s were easily recognizable to collectors as "Cabrals" due to his signature style in representing the female form. ${ }^{28}$ Cabral's women were essential to his art.

Cabral started illustrating covers for Revista de Revistas in 1920, soon after his return from Europe and Buenos Aires. As many of his predecessors in Paris, Cabral was drawn to the glamour of the Demimonde, expressed in the interplay of bright lights and dark shadows of the bustling metropolis, where the nightlife of the rich-opera, theater, restaurants-contrasted with the pleasures of the poor,

25. For a detailed discussion of the many guises of the modern woman in Mexico, see Joanne Hershfield, Imagining the Chica Moderna: Women, Nation, and Visual Culture in Mexico, 1917-1936(Durham: Duke University Press, 2008).

26. Barrow and Katz, "Ernesto Cabral," p. 17.

27. Ibid., p. 18.

28. Ibid., p. 20. 
portrayed through the many facets of street life. Inspired by his recollections of bohemian Paris, Cabral's drawings drew on the tenets of Art Nouveau, and transposed such stock urban characters as society women, prostitutes, and pimps into the landscape of Mexico City. By 1925, however, when he captured the essence of the Bataclán for a February cover of Revista de Revistas, Cabral's style had changed markedly and the frills and embellishment characteristic of Art Nouveau had made way for the simple, elongated lines of Art Deco. ${ }^{29}$ In the Bataclán cover, Cabral contrasted a well-lit, graceful dancer against a dark, circumspect audience of upscale male spectators (Fig. 1). Reducing the stage to a single line and rendering the dancer in both profile and straight on, Cabral's use of space is ingenious; he captures the intricate movements of the dancer's body while revealing only a slight glimpse of her face and eyes. Slender but strong, elegant but indifferent, and sexy yet androgynous, she appears to be walking a tightrope, harmonizing feminine fragility and sexual boldness. The men, stirred but baffled, take in the spectacle.

Importantly, Cabral's art communicated that even mestizo and indigenous Mexican women could aspire to the new beauty ideal. Week after week, the covers of Revista de Revistas revealed that the celebration of the new female ideal, while predicated on white bodies, relied on form, not skin color. Cabral's representations of Art Deco mestizas in various shades of brown, like the "national" beauties of the Rataplan and other bataclanesque Mexican revistas, demonstrated that an authentic mexicana performed modernity just as well as any other Deco girl when fitted into the right shape and equipped with the appropriate attitude. (Fig. 2).

Cabral's black-and-white drawing En el Ba-ta-clán (Fig. 3), a composite of the performances on either side of the stage, gets closer to the totality of the spectacle; the elongated dancers, statuesque while in full movement, are alternated with caricatures of the audience. Cabral's unforgiving close-ups of gawking, lusting, and incredulous older upper-class "gentlemen" and one indignant wife (portrayed as an older, unattractive woman) invokes well-ingrained stereotypes of gendered behavior, but also foreshadows the poor abuelitas and mamás of Santa Anita's Festival of Flowers that the reporter of $E l$ Globo would invoke a few months later.

Cabral's covers spoke not only to a large popular audience, but equally to the budding mass media of modern journalism and mass marketing of which his work was an integral part. Joanne Hershfield argues that due to Mexico's high illiteracy rates, modernization and development in Mexico were in large part "dependent

29. Barrow and Katz note that during the lengthy time Cabral worked for Excélsior with accent over the second $\mathrm{e}$ Excelsiór, he masterfully wove all he had absorbed into a signature style. Yet, they do not seem to recognize the progression in Cabral's work from Art Nouveau (the early period of his covers for Revista de Revistas) to the later Art Deco of the mid-20s. 


\section{Figure 3}

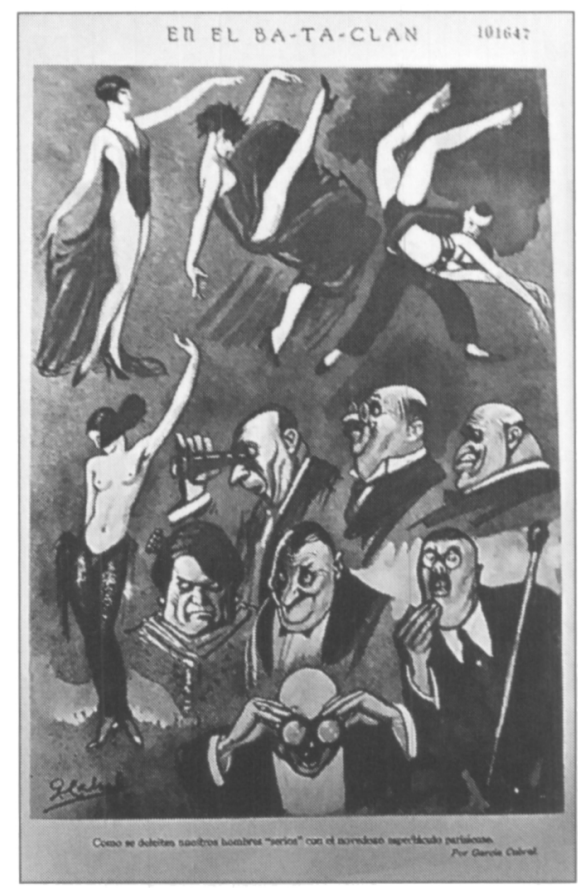

"Como se deleitan nuestros hombres 'serios' en el novedoso espectáculo parisiense."

(How our 'serious' men delight in the novel show from Paris.)

Source: Ernesto García Cabral, "En el Ba-ta-clan," Jueves de Excélsior, February 26, 1925.

on the circulation of a global visual culture." 30 Cabral's distinct way of seeing reverberated in news photography, journalistic reports, and advertisements, constituting a visual economy that permeated the capitalinos' collective consciousness. By the mid-1920s, Hollywood had effectively demonstrated that entertainment was big business, both in terms of ticket sales and the role it played in creating new consumer markets. ${ }^{31}$ Intersecting historically with the rise of modern journalism, as well as the mass production and consumption of beauty products, Deco body of the silver screen provided transnational beauty industries with a new tool for selling merchandise in Mexico as well. Some advertisers simply inserted Deco bodies into campaigns for pre-existing goods, yet new products also proliferated that promised consumers ways to attain the Deco body through their use.

30. Hershfield, Imagining the Chica Moderna, p. 12. See also Rubén Gallo, Mexican Modernity: The Avant-Garde and the Technological Revolution (Cambridge: MIT Press, 2005), Chapter 1.

31. Kathy Peiss, Hope in a Jar: The Making of America's Beauty Culture (New York City: Henry Holt and Company, Inc., 1998), pp. 152-4. See also Hershficld, Imagining the Chica Moderna, p. 67. Hershfield notes that Hollywood and the garment industry established links between cinema and new fashion, with department stores in major U.S. cities copying styles worn by popular actresses in major feature films. 
In the early 1930s, opinion and editorial articles warning women to guardar la linea (save their lines) by propagating weight loss and exercise, increased dramatically. Advertisements with a focus on enhancing the female form through the use of stockings, shoes, and dresses to create the appearance of increased height, and ones that guaranteed female readers "breasts like a statue" proliferated in the early $1930 \mathrm{~s},{ }^{32}$ while announcements for skin-whitening cream that had been so popular during the Porfiriato significantly decreased. A new understanding of female beauty articulated by Deco bodies on stage, whether in the theater or in a shop window, called for a new aesthetic of seeing. Popular magazines and even newspapers in the capital city increasingly published photos essays on the quest for bodily perfection where step-by-step preparation of engineering beauty could be captured and shown. Hershfield explains that fashion provided women with an acquisitive gaze-a consumerist "erotics of looking"-where female consumers learned to identify with models and to desire inhabiting their Deco bodies. ${ }^{33}$

The origins of the Deco body can be traced to Europe and the United States during the First World War. As early as 1913, Gabriele 'Coco' Chanel sold her first collection of radically novel clothing that freed the waists and legs through new fashions that "blurred the line between masculine and feminine." 34 Chanel's garçonne style would have remained largely unknown, catering only to the rich and eccentric, had it not been for the effects of the Great War, when hundreds of thousands of European and American women entered the workforce. The loose-fitting, comfortable clothing left much room for movement, allowing women to engage in work and play with much greater ease. And in the United States, the image of the flapper was fashioned in large part by writers such as Scott E. Fitzgerald, who proclaimed that the flapper's identity stemmed not only from the "shape of her body and placement of her curves," but also from the products she consumed. ${ }^{35}$

While the entertainment industry advanced its desirability, other commercial culture industries - the beauty industry in particular - were quick to appropriate the Deco body as their main vehicle in selling an array of luxury, yet affordable products marketed to middle- and lower-class women. By the 1920s, consumption was conceived of as a feminine activity, and the advertising industry marketed products to a primary female audience "regardless of class." 36 Shopping promised women freedom from patriarchal constraints, even if this consumption did not necessarily destabilize traditional gender relations or result in a comprehensive

32. Universal Ilustrado, May 3, 1934, p. 69.

33. Hershfield, Imagining the Chica Moderna, pp. 51-52. Hershfield agrees that it was not merely the clothes, but also the body type of the models that taught Mexican women how to be modern.

34. Joshua Zeitz, Flapper: A Madcap Story of Sex, Style, Celebrity and the Women Who Made America Modern (New York City: Three Rivers Press, 2006), pp. 153-154.

35. Ibid., p. 158.

36. Hershfield, Imagining the Chica Moderna, pp. 33 and 59. 
Figure 4

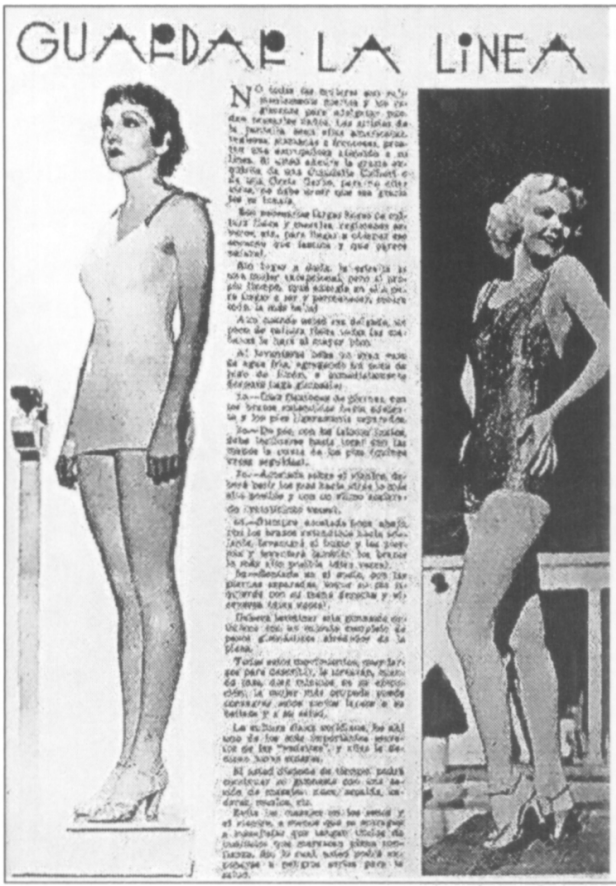

Source: Revista de Revistas, January 5, 1936.
Figure 5

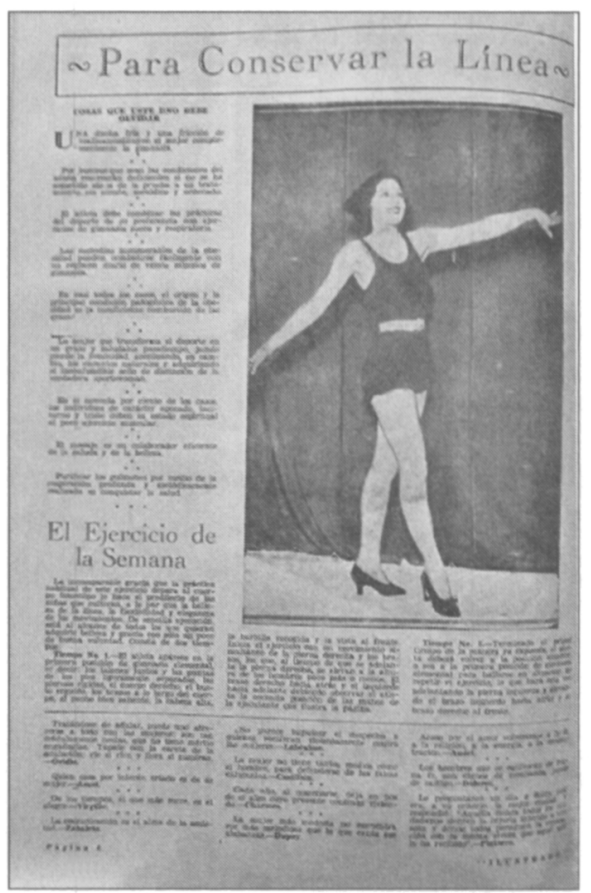

Source: Universal Ilustrado, July 9, 1931.

independence for women. ${ }^{37}$ The advertising industry found eager consumers in young women who sought to express their independence, but who looked to theater and film for cues about products that would accomplish the image and style that symbolized that freedom. While the flapper communicated individuality, she expressed this in consumer conformity. ${ }^{38}$ In Mexico, the flapperista equally sold an array of products (fashion, cigarettes, creams, automobiles), yet similarly associated the modern woman with rebellion, controversy, and self-determination, liberating as well as commodifying feminine independence. ${ }^{39}$

Although this incipient form of transnational gendered capitalism might have not been empowering in a feminist sense, the world of leisure and shopping did provide working-class women with a sense of mobility, freedom, and female sociability. In the United States, entertainment and leisure became important strategies

37. Nan Enstad, Ladies of Labor, Girls of Adventure: Working Women, Popular Culture, and Labor Politics at the Turn of the Twentieth Century (New York City: Columbia University Press, 1999).

38. Ibid.

39. Hershfield, Imagining the Chica Moderna, p. 59. 
in working women's constructions of self, definition of their autonomy, and access to the public sphere. Most young women in New York City at the turn of the century sought out types of employment that would facilitate their access to cinemas, theaters, clubs, and dancehalls. Shopping also served as entertainment. ${ }^{40}$ Working women's mobility in large cities in both the Unites States and Mexico provided them with ways to "enact public subjectivities" based on their identity as consumers. ${ }^{41}$ Working women now looked around with an "active" gaze on the street and in the theater. This consumer gaze was part of a larger cultural fabric of wishes and expectations, yet one that legitimized women's presence in public, and active participation in the construction of her own desires.

Changing ideas of beauty reached Mexico also largely by way of the entertainment industry. ${ }^{42}$ Mary Kay Vaughan and Rubén Gallo suggest that in Mexico, emerging consumer culture revolved in large part around "public spectatorship" produced by new urban spaces, namely department stores, parks, dance halls, theaters, photography, trams, boulevards and stadiums. ${ }^{43}$ Writer and social commentator Salvador Novo argued that not until the 1920s did Mexican women have the equipment at their disposal to perfect their looks, even if this entailed a standardization of beauty he largely blamed on the popularity of cinema. Women embarked on weekly—and lengthy-visits to beauty parlors to dye their hair, have their eyebrows plucked, undergo facial clay mask treatments, and receive manicures all in an effort to emulate the statuesque beauty of "Venus de Milo." Buying garments on installment plans made it easy for most Mexican girls to dress like Joan Crawford and other Hollywood stars. Mimicry, Novo wryly commented, did not make perfect, however; "[b]etween beauty and make-up-it seems childish to emphasize it-there is the vast difference that separates life from the theater." ${ }^{44}$

The new emphasis on acquiring beauty certainly had its detractors, who seemed to worry about its power in blurring class lines and gender norms. According to Novo, the superficiality of the beauty regimen eclipsed a woman's larger charms, such as her intelligence and personality. As long as a woman had good skin, she

40. Kathy Lee Peiss, Cheap Amusements: Working Women and Leisure in Turn-of-the-Century New York City (Philadelphia: Temple University Press, 1986).

41. Enstad, Ladies of Labor, pp. 52,161, 181. Hershficld, Imagining the Chica Moderna, p. 41. Hershfield agrees that even if the lower class was not able to afford most foreign fashion and luxuries advertised in magazines, or displayed at Palacio de Hierro, they understood "the freedom to window-shop."

42. "Nuevo Mundo: La Señora Gana Mas," El Nacional, December 21, 1941, p. 8. Mexican women learned about successful businesswomen such as Helena Rubinstein, who by the late 1930 s headed a cosmetics empire. Hershfield also remarks that most of the merchandise on display in large department stores in Mexico City were of U.S. or European origin.

43. Mary Kay Vaughan, "Pancho Villa, the Daughters of Mary, and the Modern Woman: Gender in the Long Mexican Revolution," in Jocelyn Ollcott, Mary Kay Vaughan, and Gabriella Cano, eds., Sex in Revolution: Gender, Politics, and Power in Modern Mexico (Durham: Duke University Press, 2006), p. 23. See also Gallo, Mexican Modernity, pp. 201-226.

44. Salvador Novo, "Los feos concursos de bellcza," México al Día, December 1, 1935, pp. 36-37. 
could be malcriada (badly raised) and brusca (rude). Female columnists equally warned against the "female problem" of vanity. In her weekly advice column for women in Mujeres y Deportes, Carmina suggested that a lack of proper education was at the root of women's focus on appearances and other "useless things" that characterized the "painted woman," including an overly intellectual and "cold" approach to life. Instead, Mexican women should stress their wisdom and humility, and embrace the motto, "I know that I don't know anything." 45

Despite Novo's and Carmina's protests, the quest to realize the ideal of statuesque beauty through a regimen of diet, exercise and products to discipline the body had become a mainstay of the popular press by the late 1920s and early 1930s. Advertisements for U.S. make-up, French perfumes, and Mexican facial creams frequently appeared in popular publications and highlighted their growing presence in the city's pharmacies, clothing outlets, and smaller retail stores. ${ }^{46}$ Advertisements for beauty products accompanied articles that stressed the need to cuidar sus lineas through diets that would produce rapid weight-loss, and daily exercise to tone and lengthen the body. These articles appeared frequently as part of, or followed by, stories on Hollywood, as well as Mexican, stars and starlets. In these stories, the Deco bodies of movie stars functioned as the highest, but attainable, goal to stay slim and to engineer good skin. Often beauty advisors to the stars and other experts revealed some of their trade secrets that taught female readers to subject themselves to "the rules of health in order not to lose their lines," to walk gracefully (stars, used to the ever present camera, learned to have better posture), and strategies to lose thigh and belly fat. ${ }^{47}$

If the mass media propagated new beauty ideals through a visual economy of Deco bodies, the revolutionary state largely determined to what extent women would have access to the new beauty products. Public Health officials, however, differed little in their assessments of what constituted beauty from those who developed, marketed and sold an ever-growing array of beauty products. The classification, production, and sale of beauty products in Mexico was regulated by the Department of Health. In 1928, the Secretaría de Salubridad Pública drew up a new ordinance that considered both drugs and beauty products as part of the same category of pharmaceuticals. Hence, "abortivas" (abortifacients), which could be obtained in drugstores with a doctor's prescription, were mentioned in

45. Carmina, "Para Ellas," Mujeres y Deportes, August 11, 1934.

46. "Circular 550," November 14,1927, in Archivo Histórico de Secretaría de Salubridad Pública y Asistencia, Mexico City (AHSSA), Salubridad Pública (SP), Servicio Jurídico (SJ), box 8, file 1. Transactions in beauty products were not restricted to pharmacies. Roberto Medellín, secretary of Department of Health, allowed for the sale of beauty products in clothing stores on the condition that the store employed a designated person-with or without a pharmacy credentials-to handle the sales of beauty products.

47. Carmina, "Cómo reducir las cadcras y el abdomen," Mujeres y Deportes, November 3, 1934, p. 5; "Las reglas de salud a que se sujeta para no perder la linea," Mujeres y Deportes, December 8, 1934, p. 21. 
the same legislative article that regulated hair products. ${ }^{48}$ As the Department of Health articulated its regulations in terms of health through beauty, government officials followed the beauty industry in viewing beauty products as a logical extension of the search for health. This also meant that beauty products largely were sold at pharmacies, which conferred additional scientific and medicinal legitimacy on beauty regimes and on aesthetic products. ${ }^{49}$

Engineering beauty was presented as a scientific enterprise that could be taught and learned, with or without products. Dispatches from Hollywood and New York City showed Mexican women how U.S.-style beauty was merely a matter of education. Articles translated from English advocated a commitment to a healthy lifestyle that would lead one to beauty. A routine of nine hours of sleep, sports, and a clean face, underscored that the investment of time and discipline, as much as the use of beauty products, was crucial in attaining a Deco body. ${ }^{50}$ "Inside the temples of beauty," a photo essay about beauty schools in the United States, showed the classroom as the scientific stage where girls performed applying masks, massaging the scalp to shampoo hair properly, used correct make-up, and slapped chins to fight sagging facial muscles. Photographs captured the end result of the transformation: a series of nearly homogenized faces and Deco bodies. ${ }^{51}$

The idea that Mexican women might become like all other women in their quest for universal beauty presented some male readers and commentators with cause for concern. As the perception of an authentic Mexico resided in what I call the camposcape, an anachronistic and feminized countryside tied to national essence, tensions between the female beauty ideal presented by modern, urban, and androgynous-looking Deco bodies and the idealized feminine embedded in indigenismo found their clearest expression within debates over a suitable national identity. ${ }^{52}$ Male readers of the weekly publication Mujeres $y$ Deportes complained about the magazine's heavy emphasis on Hollywood beauties at the expense of the charms of Mexican women. The editorial staff remedied the situation by including a photo page of "typical Mexican ladies" with photos and captions that invoked a gendered classification of race and place reminiscent of colonial casta paintings. "From Guadalajara, Latina, cultured and Indian" read the caption

48. "Reglamento para el registro y certíficación de medicinas de patente, especialidades, y productos de tocador, higienicos de belleza, y demas similares," in AHSSA-SP-SJ, box 11, file 7.

49. "Circular 550," November 14, 1927 in AHSSA-SP-SJ, box 8, file 1.

50. "Norma Shearer: A los 30 años comienza la vida de la mujer," Mujeres y Deportes, July 7, 1934.

51. "En los templos de la belleza," Mujeres y Deportes, January 1, 1938, pp. 66-73.

52. While "camposcape" is the terminology I use to describe the feminization of rural landscapes in the service of constructing an authentic Mexican national identity, I refer the reader to Stacie G. Widdifield, The Embodiment of the National in Late Nineteenth-Century Mexican Painting (Tucson: University of Arizona Press, 1996) for a detailed discussion of the role of feminine bodies as allegories for the nation in nineteenth-century landscape painting, and to Debra Poole, "An Image of 'Our Indian': Type Photographs and Racial Sentiments in Oaxaca, 1920-1940," Hispanic American Historical Review 84:1 (2004), pp. 37-82, for a treatment of visual Indigenismo in photography. 
underneath a photo of a young mestiza woman, followed by photos with captions such as "from a Spanish father and Indian mother, the result is," "product of a Spanish father and French mother equals a true Mexican woman," and, finally, the modern, capitalina girl as the "representative type of youth in today's Mexico."53 Photo-illustrated searches for the most beautiful woman in Mexico based on these racial and regional types equated women with landscapes much in the way that early European images of the "New World" depicted male conquistadors and explorers taking possession of an America symbolized by indigenous women. ${ }^{54}$

Thus, the fear of homogenized beauty centered not so much on the condemnation of the outward appearance of Deco bodies in favor of inner beauty, charm, and personality as cronistas such as Salvador Novo first seemed to suggest, but rather on the danger of compromising the markers of class and mexicanidad. The "ugliness of beauty pageants," Novo reasoned, was that they did not take into account regional and ethnic variance. In describing this difference, however, Novo equally resorted to the well-ingrained habit of casting racial difference as a gendered landscape. "Today," he wrote in 1929, "we can distinguish principally between the following types of Mexican women: white, corn-colored, and dark; from those again we can distinguish those who live in the tropical valleys and those who have been born in the fresh and romantic mountains." 55 In contrast to the countryside, Novo saw women from Mexico City as elegant, slender and Latina. While unnecessary, according to Novo, the capitalina used cosmetics quite liberally, and this enhanced the bodily difference that set her apart from rural mexicanas. Yet, the capital city also counted a vast and ever growing number of rural women, who-removed from the campo-Novo labeled as "Indio." These "unwashed masses," he stated matter-of-factly, generally did not make "the slightest effort to hide their bronzed color with help of powders and other cosmetics."

If female bodies signaled that health constituted beauty, and beauty health, they could only function as proper markers of nation and modernity when confined to their proper place. The built environment, Elizabeth Grosz finds, "provides the context and coordinates for contemporary forms of body." ${ }^{27}$ Yet, understandings of embodiment also give shape to urban space. Deco bodies informed the modern city. Deco bodies, while packaged and marketed by Hollywood for the rest of the

53. "Asi las miran in Yanquilandia: ¿Este usted de acuerdo?," Mujeres y Deportes, January 8, 1934, p. 94.

54. "De donde es la mujer mas bonita de la republica," Mujeres y Deportes, August 25, 1934, p. 7. For examples of sexualized and feminized landscapc in early modern European depictions of the Americas, sec the image, "Anerica," ca. 1575 by Jan van der Straet cited in Ann McClintock, Imperial Leather: Race, Gender and Sexuality in the Colonial Contest (New York City: Roudlege, 1995), p. 25. For discourses on rituals of possession in European colonization of the Americas, see Patricia Seed, Ceremonies of Possession in Europe's Conquest of the New World, 1492-1640 (Cambridge: Cambridge University Press, 1995).

55. Salvador Novo, Revista de Revistas, September 8, 1929, p. 5.

56. Ibid.

57. Grosz, "Ciry-Bodies," p. 104. 
world and imagined as white, spoke to Mexicans because of their essential emphasis on a new form that connected them with modernity. Form, not race, became the dominating feature of this new ideal. As such, the Deco body formed a bridge from Indigenismo to Mestizaje, rather than a contrast. By looking at the nameless stars of the Bataclan, and soon thereafter the Mexican Rataplan, Mexican women of all ethnic backgrounds could imagine themselves as modern beauties. All one had to do was slim down, grow tall (i.e., wear heels and waist-less dresses), use make-up accentuating the eyes and the mouth, and act the part.

\section{MAPPING MODERNITY}

Through visual media, Mexican women, like their counterparts elsewhere, learned to dress, use make-up, slim down, and even consider plastic surgery as they beheld extremely popular female entertainment stars. ${ }^{58}$ Moreover, the appearance of Mexico City itself changed significantly during the 1920s as U.S. cultural influence altered not only the dress and demeanor of its inhabitants, but also the built environment. The city experienced a near U.S. invasion of products that followed on the heels of famous movie stars, as U.S. writer and traveler Anita Brenner noted, and neon signs almost made one forget the existence of the vecindades. ${ }^{59}$ The sheer proliferation of images signaled to capitalinos not only what the city was becoming, but even more how it could be imagined. Anne Rubenstein argues that the cultural transformation of Mexico City was the culmination of long-term developments, including an increase in economic growth, literacy rates, and advertising, which by the 1930s had left their marks on the urban landscape. ${ }^{60}$ The advertisements, echoing Cabral's work for Revista de Revistas and other entertainment magazines, were indicative of a new age of seeing, influenced by the advent of cinema, technological advances in photography, and the idea that women's mobility in urban, public spaces was a requisite for modernity.

Like other artists, architects had learned to think about the built environment as an expression of female beauty for some time. During the Porfiriato and early revolutionary period, architects learned to conceptualize the design of buildings through an aesthetic of female appearance. The Secretaría de Educación Pública (SEP) stipulated that a thorough knowledge of the proportions of the human body acquired through drawing was of principal importance to the study of archi-

58. Male stars in Mexico of the period were typically comedians (Leopoldo Beristain, Roberto Soto, Cantinflas) and it would take until the advent of Mexico's Golden Age of cinema-starting in the late 1930s-before male stars would be billed and sold as full-fledged sex symbols.

59. Anita Brenner, The Wind That Swept Mexico (Austin: University of Texas Press, 1973), p. 80.

60. Anne Rubenstein, "Mass Media and Popular Culture in the Postrevolutionary Era," in Oxford History of Mexico, William H. Beezley and Michael Meyer, eds. (Oxford: Oxford University Press, 2000), pp. 639, 641. 
tecture ${ }^{61}$ While students copied models from photographs or plaster, they also had ample opportunity to sketch life subjects, which were often nude female models.$^{62}$ Not until the fourth year of study did students spend most of their time concentrating on the technical facets of architecture, such as architectural theories, topography, building materials, legal codes and "hygiene," i.e., the construction of healthy spaces through sanitary facilities and sufficient ventilation. ${ }^{63}$ The focus of their training consequently did not consist of technical and architectural aspects, but more of aesthetics through the drawing of plants, animals, and other ornamentation of the classic female nude ${ }^{64}$ Consequently, young architects who came of age during the late Porfiriato and early revolutionary years learned to conceptualize buildings based on their visual interpretation of human bodies, the female body in particular.

Art Deco offered these architects the familiar concept of generating feminine beauty through the built environment, but provided new, simplified, elongated designs and sparse ornamentation that characterized the new ideals of feminine embodiment, through—as some architects stated- "nude" forms. ${ }^{65}$ In her illuminating work on the relationship between Art Deco and the female form, Lucy Fischer finds that Art Deco, "manifests a particular fascination with the figure of Woman," especially as this woman was no longer tied to nature like the art of previous epochs but rather exemplified the machine age. Rendered "more neutral" and small-breasted, Art Deco's rendition of the female form, argues Fischer, sought to wrest it from the realm of maternity. ${ }^{66}$

Named "posthumously" in the 1960s after the 1925 Exposition Internationale des Arts Décoratifs et Industriels Modernes, Art Deco referred to the style that surfaced between 1910 and 1935, and influenced a vast array of material culture: fashion, arts, jewelry, housewares, architecture, and interior design. Known at the time simply as Style Moderne, it was the successor of Art Nouveau, which had been abandoned by the start of the First World War. While Deco artists shared in the exotic and hedonist legacy of Art Nouveau, they also sought to fashion a new style that would reflect modernity. Even if retaining Art Nouveau's Orientalism, it rejected the emphasis on nature and on natural form. Instead, Art Deco looked

61. Secretaría de Educación Pública (Mexico City), Boletin de Instrucción Pública, 1:5 (May 10, 1903), p. 345. The Plan de Estudios de la Escuela Nacional de Bellas Artes that outlined the study of architecture at the prestigions school of Fine Arts, ensured that aspiring architects-the majority of whom were men-spent most of their time in the classroom cngaged in drawing. Secretaría de Educación Püblica (Mexico City), Boletín de Instrucción Pública, 22: 1, 2, 3 (July, August, September 1913), pp. 306-307.

62. Ibid., pp. $95,97$.

63. Ibid., pp. 92-93.

64. Ibid., p. 342.

65. Art Deco inspired Mexican architects such as Antonio Muñoz García, who used the concept of nudity in describing his work. See notes 58 and 59.

66. Fischer, Designing Women, pp. 26, 32. 
to the modern city, and hence was referred to by some as the "skyscraper style." In its imagery and graphics, Art Deco celebrated mechanical production, speed, and efficiency, fostering collaboration between industry, mass production, and art. ${ }^{67}$ Unlike more radical Modernists, Deco artists embraced consumerism. However, if Art Deco shared the sense of an aesthetic modernism with its predecessor, it lacked its social concerns. ${ }^{68}$

In the debates among architects during the late 1920s and early 1930s about what style would best exemplify a Mexican national character, Art Deco provided warring factions with a conciliatory position. Most of Mexico's foremost architects were divided into two camps: Those who opted for a neo-colonial style that best fit the city's "historic district"; and those who believed the revolution would be best served by stripped-down Modernism. These architects proposed that not only new times but also advances in technology and innovative building materials necessitated a reconceptualization of form. ${ }^{69}$ Frederico Mariscal, who designed and built the Teatro Iris and finished the Art Deco interior of the Palace of Fine Arts, came down on the neo-colonial side of the fence. Mariscal believed that "beauty" could not be separated from the totality of architecture and that functionalism was too narrow in its objectives. Hence, architects should continue to identify as artists, who learned their art through drawing and modeling. Many of the era's architects engaged in urban reform agreed with Mariscal that functionalism should be conceived of in terms of architecture, and not as a socio-political project. ${ }^{70}$ Ultimately, Art Deco best expressed a modernist aesthetic that Mexican architects in search of a mestizo modernity could live with. ${ }^{71}$ In part, this reflected fears of communism fostered by Mexican architects like Mariscal, who were political conservatives, and viewed functionalism as too close to emulating communist architecture.

As an academic movement, Art Deco offered both scientific principles and an alternative aesthetic to a society not quite ready to "assimilate the nudity of forms" inherent in Modernism. ${ }^{72}$ Yet, the "nudity of forms" and the sense of engineering beauty predicated on the female form dominated the architectural debates of the era and structured some of the critical differences between the radical and moderate modernists. Radical modernists were seen as functionalists resorting to the "extreme lines" of Neue Sachlichkeit (New Objectivity), while

67. Ibid., pp. 13, 16, 18 .

68. Paul Greenhalgh, “A Strange Death," in Paul Greenhalgh, ed., Art Nouveau, 1890-1914 (London: Victory and Albert Museum Publications, 2000), pp. 431-2, 436; Fischer, Designing Women, pp. 11-12.

69. Dirección de Arquitectura y Conservación del Patrimonio Artistico Inmueble, Pláticas sobre arquitectura, 1933. Cuadernos de Arquitectura, no 1. (Mexico City: Conaculta, 2001), p. 41.

70. Ibid., pp. 50,53 .

71. Ibid., p. $x$.

72. Ibid., p. vii. 
moderates believed that modernist architecture did indeed possess the ability to generate beauty, even without ornamentation. Antonio Muñoz García, an architect who executed several large public works projects in Mexico City during the early 1930s, underscored the importance of beauty in fashioning this new, nude architecture: "We will undress architecture, but not until we are sure to have found beautiful lines, and beautiful forms so we can show them without offending good judgment and the right intent." ${ }^{.73}$ Architecture of today, he reasoned, had become simplified, "leaving nude the elemental forms" much in the same way that ads for beauty products promoted Deco bodies and the Bataclán had undressed the Deco bodies of its dancers in the name of tasteful art;

today, in order to undress, a woman first makes sure she has a buena linea, and if not she seeks it by making sacrifices. To reach the best aspect of youth and health, she uses lotions and cosmetics, because if her nudity reveals ugliness, it will arouse pity, hilarity or repugnance, while showing off beauty produces applause. Ugliness prefers to cover itself at any costs. ${ }^{74}$

In keeping with Fisher's insight that "a discourse on sexual difference" informed the Art Deco aesthetic, Mexican architects like Muñoz conceptualized buildings as female bodies. ${ }^{75}$ One could undress them to show their health, their fine lines, and their beauty, or one could torture their natural forms into monstrosities in need of coverage. Architecture without beauty, he concluded in dramatic fashion, "would cease to be architecture." "76

The feminine "fine lines" of new buildings that Art Deco offered did not resemble just any female body, rather it was the nude, slim physique of the bataclana. According to Mark Winokur, Art Deco was tied not to the domestic sphere, but rather to the world of entertainment; lavish set designs, costumes, and dance postures that influenced designs to transform stars into "sculpturesque pieces." 77 Silvano Palafox, responsible for the first Deco structure "El Nacional" built in the historic center, also placed his architectural philosophies within the context of theatrical performance. Speaking out against functionalism, Palafox argued that an architect should design buildings to satisfy man's "spiritual needs," such as the need to enjoy "a show at Teatro Lírico." ${ }^{78}$ As this theater was known for its spicy revistas featuring pretty bataclanas, he equated the search for architectural beauty with female nude spectacle. For Palafox, a building could only be beautiful if it was functional in the broad-

73. Ibid., p. 60.

74. Ibid., pp. 59-60.

75. Fischer, Designing Women, p. 27.

76. Pláticas sobre arquitectura, p. 60.

77. Mark Winokur, American Laughter: Immigrants, Etbnicity and the 1930s Hollywood Film Comedy (New York City: St. Martin's Press, 1996) quoted in Fischer, Designing Women, p. 25.

78. Pláticas sobre arquitectura, p. 82. 
est sense, that is, if it served man's "aesthetic emotion."79 As with the engineering of fit bodies, beauty equaled health in the design of new buildings.

The use of Deco bodies in entertainment mirrored Modernist and Deco conventions in art, such as the serialization of objects, emphasis on functionality, and the simplification of ornamentation, reflecting a modern society dominated by new technologies. Like the homogeneity of mass production exemplified by the conveyor belt, modernist aesthetics promised a sense of order in a fairly chaotic world. Whether modernist architects agreed or disagreed on the need for beauty mattered little in the face of its centrality - whether marked by presence or absence-and the understanding that the female body formed its suitable blueprint. The fact that architectural designs followed closely in the footsteps of the new physiques formulated by the world of show business underlined that spectacle and the "art of seeing" structured contemporary ideals of what form the city should take.

\section{Acting Out the City}

In the wake of the Bataclán, women aspiring to modern gender norms did appear to enjoy greater mobility in Mexico City. The success of Bataclán-like shows and the allure of the Deco body created a discourse of a new femininity that helped women to take firm steps outside of preconceived roles. As the Bataclán glorified Deco bodies with short hair, it validated the struggles of the pelonas a year earlier, in 1924, when young women with short hair had endured physical attacks by men. ${ }^{80}$ Not only did bataclanismo make it easier for Mexican women to cut their long trenzas (braids) ${ }^{81}$ and buy high-heeled shoes, but the acts of Deco icons such as Lupe Vélez with her outlandish behavior, independence, and devotion to dancing the Charleston, propelled them out of their class and ethnic boundaries and their usual areas of town. ${ }^{82}$ In the early 1920 s, elite women did not frequent drinking establishments other than Café Colon-the epicenter of refined society-and Sanborn's, where elegant ladies would meet between 5-7 p.m. to partake of refreshments and ice cream while listening to German Operetta playing in the background and, reportedly, look for blond men. ${ }^{83}$ At the end of the decade many upper- and middle-class women in search

79. Ibid., p. 83.

80. Anne Rubenstein, "The War on 'Las Pelonas': Modern Women and Their Enemies, Mexico City, 1924," in Jocelyn Ollcott, Mary Kay Vaughan, and Gabriclla Cano, eds., Sex in Revolution: Gender, Politics, and Power in Modern Mexico (Durham: Duke University Press, 2006), pp. 57-80. Pelonas literally meant bald women, but was used in reference to any women who decided to get short haircuts.

81. Braids were considered a crucial element in the construction of traditional Mexican femininity.

82. Lower-class women historically had enjoyed a much greater physical mobility and access to the street than middle-class and upper class women, for which they were often condemned.

83. Salvador Novo, Revista de Revistas, September 8, 1929, p. 5. 
of their own adventures and bohemian nightlife, had begun to explore the carpas and dance salons near Plaza Garibaldi, an area that had been officially set aside for legalized prostitution by $1918 .^{84}$

Crossing over to "the dark side"-slumming even-became more acceptable and enticing to these women by the end of the 1920s and into the early 1930s. Not only did actresses have greater independence in deciding where to perform, female spectators were increasingly attracted to the fashionable spectacle of street theater, even in small alleyways.$^{85}$ Moreover, a very visible segment of middle-class women now stayed out all night drinking in cabarets. These women, so tells Salvador Novo, made up the female half of the nouveau riche who self-identified as "modern," bought Ford cars on installment, and slept in late on Sundays, awakening only in time to attend a movie. ${ }^{86}$ In promoting female social and physical mobility, bataclanismo not merely mirrored how modernity changed gender norms in Mexico, it helped to facilitate that change. ${ }^{87}$

Still, in order for women to claim that modernity, one had to act the part. The role of the quintessential modern girl was difficult to perform, as the chica moderna seemed to be an enigmatic "hybrid creature." 88 On one hand, her Deco body appeared androgynous, on the other she exuded a bold feminine sexuality. In owning her own money and her own body, the modern girl seemed to own modernity. Looking young and boyish, and acting as a deviant girl, the chica moderna certainly did not appear innocent. Her behavior was practical, even manipulative, but no longer in the dramatic style of the diva. In dressing, dancing, and smoking in a provocative manner, she embodied the new liberated woman, a transnational emblem of the ascendancy of global capital and Western modernity. Joanne Hershfield agrees that images of the chica moderna, while circulating within nationalist discourses, were specifically representational of global modernity, yet "the modern Mexican woman was not merely a carbon copy of her U.S., British and German sisters, a 'flapper' who spoke Spanish."89

As such, the chica moderna proved an unstable signifier at the crossroads of revolutionary reform and national development. In modeling herself after flappers from the United States and Europe, her metropolitan identity fit well with rev-

84. Jeffrey M. Pilcher, Cantinflas and the Chaos of Mexican Modernity (Wilmington: SR Books, 2001), p. 22. For prostitution zones in Mexico City, sce Bliss, Compromised Positions.

85. Diversiones, August 13,1932, p. 15. In 1932, the attraction of outdoor strect theater spoke to the imagination of capitalinas as the "Jaime Nunó alley" became the epicenter of spectacles en vogue. A dancer who once had celebrated legendary successes in the cabaret Molino Verde on Plaza Garibaldi now made a greater spectacle of herself passing through the neighboring streets with great fanfare and performing in alleyways.

86. Salvador Novo, "Que hacer Los Domigos," Nuestra Ciudad, August 1930, pp. 6-7.

87. Pilcher, Cantinflas, p. 20.

88. Hershfield, Imagining the Chica Moderna, p. 5.

89. Ibid., p. 6 . 
olutionary dictums of economic modernization through industrialization, urbanization, and the fomentation of tourism. Ascendant middle-class leaders from the outward-looking state of Sonora pitched the revolution as a young, modern and innovative movement, bent on fashioning real social equality. Its cultural programs attracted artists and bohemians with radical sentiments and lent the revolution a progressive, irreverent allure. ${ }^{90}$ The chica moderna seemed at odds with revolutionary nationalism, however, especially in comparison with the indigenous women who took center stage in many of governmental commissioned murals as enduring symbols of the nation that communicated the authenticity of the Revolution. The humble indigena, often depicted as campesina, teacher, but above all, mother, was a powerful reminder that the revolutionary agenda did not include gender parity in envisioning social reform. In her search for social and physical mobility, the chica moderna clashed with the mainstay of revolutionary programs for women that allowed women a measure of power only as mothers. And a traditional, abnegating mother, the chica moderna certainly was not.

The movement of chicas modernas and their appropriation of the Deco body with its multiple positionalities ran directly counter to modernist longings for a feminized countryside as well as revolutionary ideas of acceptable feminine roles. In the late 1920 s and early 1930 s, the general perception of women's social mobility became intrinsically tied to their financial and sexual independence. In this construction of autonomy, female agency in marriage choices structured much of the public debates over what constituted femininity, especially as the revolutionary leadership passed liberal divorce laws that earned Mexico the dubious reputation of "divorce Mecca" abroad and undermined its plans to incorporate women into the revolutionary project as a domestic, unpaid workforce in the social reproduction of revolutionary citizenry.

If the choice to forego marriage or opt for divorce was at the center of women's independence and the road to female liberation, working-class chicas modernas appeared to be well on their way to freedom. In her weekly advice column "Para Ellas," Carmina explained that working women in the city found matrimony highly problematic, largely due to economic reasons. As a flaneuse on her selfproclaimed gira periodista (journalistic tour) through the city, Carmina interviewed women about marriage and concluded that most working-class women believed financially stable men did not want to marry. Instead of making what Carmina called the "double sacrifice" of marrying a poor man and still having to work, these women opted to live alone. In concluding her tour, Carmina 
described the capital as a city of women taking to the streets in forging their own destinies. $^{91}$

If the choice not to marry appeared less than alluring, the city's popular press treated divorce as a hallmark of modernity. Often discussed as part of commentary on the behavior of female entertainers, divorce was a dangerous, but not altogether undesirable consequence of Mexico's entry into the modern world. In the weekly gossip mills of sensationalist entertainment magazines, both Mexican celebrities and Hollywood stars discussed divorce as a glamorous affair. In a 1934 interview in Hollywood, the Mexican actress Dolores del Río "warned" Mexican audiences, tongue in cheek, about conjugal problems due to the abundance of temptations by "enchanting, adventurous people" that modern women such as herself were faced with. ${ }^{92}$ While female celebrity divorces, such as those of Dolores del Río and Lupe Vélez, enticed readers and sold magazines on the premise that the overt sexuality of modern women led to divorce, the problem of divorce was largely pinned on the perception of, what Judith Halberstam calls, female masculinity ${ }^{93}$ For many, the rising popularity of Deco bodies that led women to adopt outward appearances traditionally associated with masculinity-such as dress, haircuts and athleticismconstituted visible and insurmountable evidence of a drastic upset in gender norms and an imminent threat to the hetero-normative family.

The lure and danger of female masculinity that threatened the sanctity of marriage, and, by extension, the Mexican family, expressed itself in "acting out in the city," where young women claimed independence and mobility by acting not so much as men, but by behaving like famous actresses who claimed masculine traits. In the early 1930s, entertainment magazines frequently featured articles on European stars such as Greta Garbo and Marlene Dietrich who defied traditional gender roles, refused to marry, and acted in ways associated with masculine behavior. Garbo and Dietrich earned fame and fortune as new-style icons who performed as women, yet took up masculine dress, deviance and desire. In sensationalist stories such as "Marlene without pants," the popular press both celebrated and criticized actresses like Dietrich for cross-dressing. ${ }^{94}$ More than any other actress of her time, magazines used Greta Garbo to exemplify the mysterious, masculinized woman. An anomaly, Garbo embodied a cold, admired, and distanced "dominating force" not comparable to anyone, yet the woman who everyone aspired to be. In her strength and superiority, as well through her Deco body of broad shoulders and slender hips, Garbo was deemed to be the quintes$10-11$.

91. "Para ellas, sección a cargo de Carmina, la amiga sincera de la mujer," Mujeres y Deportes, July 7, 1934, pp.

92. "Hay demasiadas tentaciones," Mujeres y Deportes, August 18, 1934.

93. Judith Halberstam, Female Masculinity (Durham: Duke University Press, 1998)

94. "Marlene sin pantalones," Mujeres y Deportes, July 7, 1934, p. 22. 
sential woman of the future, "a symbol of women's emancipation." These articles were quick to point out, however, that such a woman suffered from mental disorders as part of larger sociological phenomena inherent in modernity. Psychologists explained that Garbo engaged in masculine behavior and adopted masculine dress to claim "the father's superiority," and hence was a result of persisting inequality between men and women. The warning to female readers was that masculine women such as Garbo were not empowered, but sadly remained "victims of male protest" who ultimately would reject matrimony. ${ }^{95}$

The fear of the masculinized woman who would threaten the institution of marriage and family also heightened anxiety with respect to women's presence in sports, which was touted as a desirable route in obtaining a Deco body. Mexican audiences had become aware of female athletes by the 1920s, yet the 1930s saw a wholesale participation of women in sports. Revolutionary leaders held that athletics benefited women in moderation, but exercise should in no way interfere with traditional feminine behavior. As other political parties in Europe embraced eugenics as the vehicle to engineer public health, the governmental party Partido Nacional Revolucionario (PNR) promoted male and female participation in sports as an interactive "spectacle" that would combat lower-class vice and function as the road to creating a stronger race. ${ }^{96}$ Physical education for women entailed, however, that a woman never lose her femininity. Whether belonging to the PNR, Christian youth groups, or socialist sports associations, female athletes appeared on the pages of the Mexican press as "graceful young ladies" who practiced gymnastics or formed dance groups. ${ }^{97}$ The emphasis on health within the articulation of beauty that disciplined and streamlined bodies according to the Deco body ideal, elevated sports as "physical culture" but also had to negate what Judith Butler has referred to as gender trouble.

The articulation of gender through youth and the eroticized allure of androgyny did much to appease the threatening behavior of the masculinized woman. Columnists like Carmina commented that due to exercise and other ways to achieve Deco bodies, modern women did not look like men, but rather resembled adolescent boys. Waxing eloquent about boys who lived adventurous lives, thrived on imagination, and lost their innocence in manhood, Carmina explained that boyish enthusiasm characterized modern women who "propelled themselves towards the unknown" in search of self-expression, new experiences, and new ambitions. As men grew circumspect with age and skeptical of grandes aventuras, women grew bold. ${ }^{98}$ Norma Shearer's remarks that "life began at 30" and

95. Mujeres y Deportes, August 25, 1934.

96. "Mas deportes, menos vicios," Mujeres y Deportes, August 18, 1934, pp. 3-4.

97. "La mujer mexicana ha entrado de lleno por la senda del deporte," El Universal, December 7, 1931, p. 9.

98. Carmina, "Para Ellas," Mujeres y Deportes, August 18, 1934, p. 9. 
Carmina's insights that feminism had prolonged women's youth did much to underscore that youth, or at least the impermanence of age, redeemed the modern and even masculinized woman. ${ }^{99}$

The chica moderna's "disagreeable" appearance that alienated traditional society was deemed necessary in order for women to truly emancipate themselves from the prison of the traditional family. In searching equal status before the law and functioning as the architect of her own destiny, a woman should be free to sunbathe, swim, cut her hair short, and manage her own life. However, the boyish girl, rather than Garbo's more threatening masculine femme fatale, needed to retain her innocence in order to fulfill the final goal of her independence: to be a true compañera to her man. Modern women, warned Carmina, who confused "drinks, cigarettes, and acting like a flapper" with actual modernity, who "lamentably confused liberty with libertinage," and whose only interest appeared to traverse the city in search of worldly pleasures, amounted to nothing. ${ }^{100}$ Columns like Carmina's thus instructed female readers that marriage should be modernized through partnership, rather than forsaken. Moreover, one was allowed-motivated even-to look like a chica moderna and cultivate a Deco body, as long as one did not engage in behaving like a wayward flapper.

By the end of the 1930s, the spirit of Carmina's advice had become the mainstay of the city's popular press. During most of the decade, public debates positioned the desirability of modern, more "masculine," female behavior against the idea that women could only garner more social power through motherhood. The end of the 1930s, however, saw a significant return to traditional gender norms. Advice columns and feature articles on women's issues turned increasingly towards women's duty to husband and family. Angelina's "Consultorio Sentimental" replaced Carmina's column "Para Ellas." Where Carmina had cautiously embraced modern women's independence, Angelina adamantly condemned divorce. Angelina pointed to the frivolity of Mexico's northern neighbors and the "epic proportions" of divorce in the United States, where-she believed-one in six marriages failed. Ignoring serious considerations such as domestic violence, alcoholism, and abandonment, Angelina listed trivial activities-reading in bed, listening to the radio, and feeding infants sausages-as the main reasons why the norteamericanos chose to break their nuptial vows. ${ }^{101}$ Other articles emphasized women's mental and physical strength in surviving the burdens of birth and motherhood, which made men, not women, the weaker sex. Even if the authors p. 5 .

99. Ibid., p. 13; "Norma Shearer: A los 30 años comicnza la vida de la mujer," Mujeres y Deportes, July 7, 1934,

100. Carmina, "Para Ellas," Mujeres y Deportes, August 18, 1934, p. 10.

101. "Motivos de divorcio en yanquilandia," Mujeres y Deportes, January 22, 1938, p. 93 
of these articles, who were largely women, sought to enhance women's social importance, they did so by resorting to the classic nineteenth-century construct of the moral superiority of women based on their domestic roles. Men's work paled in significance compared to the reproductive labor of a woman, these authors argued, which further highlighted gender essentialism and did not articulate any real equality. ${ }^{102}$

Morcover, popular magazines similarly advocated that Mexican women abandon their Deco bodies for a more traditional female physique. Alongside more traditionally feminine behavior, the entertainment industry of the mid- to late-1930s constructed a new sexually desirable female body and started to introduce new starlets as girl-women, not boyish girls. The rebellious flapper, the girl who had embraced androgyny and staked her claim in society as a new female being, returned home in the 1930s as a woman once again preoccupied with perfecting traditional femininity. The quest for beauty continued, but photo-essays, even in mainstream newspapers such as La Prensa, increasingly emphasized beauty as a search for a perfection of the ultra-feminine. ${ }^{103}$ Like the Deco body before it, this rearticulation of femininity was filtered through age. In weeklies such as Revista de Revistas, Diversiones, and Mujeres y Deportes as well as in dailies such as La Prensa, Mexican women witnessed an infantilization of the feminine in Hollywood, where stars dyed their hair "baby blond" and where the beauty of mature female actresses such as Carole Lombard was likened to that of child-star Shirley Temple. ${ }^{104}$ Even if journalists appeared well aware that the fashionable platinum blond was impossible for adult women to possess naturally, as it occurred only in very young Caucasian children, it spoke to an irresistible combination of a sexualized body of renewed curves and the complication of feigned innocence inherent in baby blonds. ${ }^{105}$

By the mid-1930s, the androgynous Deco body of the 1920's chica moderna had given way to the voluptuous figure of the child-woman. The attraction of this newfound representation, however, did little to elevate her status in Mexico as a woman worthy of male respect like that garnered by masculinized women such as Dietrich and Garbo. Efraín Huerta, cronista and poet, blamed Hollywood for making Mexican women into asnas (donkeys). By dressing and behaving norma shearescamente (i.e., women who acted like the popular Hollywood actress Norma Shearer), he stated, such women caused the failure of men's best-laid plans, more so as his (male) readers encountered these women not on the stage of the theater or on the screen of the cinema, but every day on the street. ${ }^{106}$ Instead of Carmina's perfect,

102. "El problema biológico y social de la mujer mexicana en nuestros días," La Prensa, November 1, 1941, p. 12.

103. "Would You Like to Be Perfect?," La Prensa, 1939.

104. Mujeres y Deportes, January 1, 1938.

105. Mujeres y Deportes, August 24, 1934.

106. Efraín Huerta, "Las mujeres asnas," El Nacional, February 21, 1939, p. 8. 
modern companions, desirable femininity had split along the lines of a voluptuous sexuality, on one hand, and a humble maternity, on the other.

\section{ConClusion}

On April 3, 1936, the Department of the Federal District's "Civic Action" committee organized a public celebration in the pueblo of Santa Anita around the beauty pageant La flor más bella del ejido. ${ }^{107}$ Representatives of all delegaciones of the Federal District competed for the honor to represent camposcape, which now entailed a national essence articulated through the accomplishments of the Revolution. The selection of the "most beautiful farm flower" was accompanied by public talks and lectures on the female emancipation that the revolution had brought. ${ }^{108}$

It had been over a decade since the urban Deco bodies of the Rataplan had invaded the pastoral idyll of the village, and near nude actresses from the city had upstaged the pretty "Indian" girl during the pueblo's traditional Easter celebration. Contrary to what the villagers might have thought, the outrageous Rataplanners did not invade the pueblo in an attempt to shock provincial mores and forcefully make campesinos confront metropolitan modernity. In fact, the National Authors Association had awarded the show with that year's first prize in stage writing and the ensemble had been invited to accept the award during the Santa Anita festivities. That the cast decided to show up in full—or rather less-regalia, remained somewhat surprising, but journalist Cárdenas' sensationalistic, hurried tone and reliance on bataclanismo's stock characters (pretty, modern girls versus jealous, indignant older women) indicated that the scandal owed more to the efforts of our cronista than to the presence of sexy actresses. What appeared more disturbing to the journalist, was that the Deco bodies, out of place in camposcape, had ruptured the rhetoric of idealized and nationalized "indígena" beauty. Bataclanismo certainly had caused a stir, but the fact that the focal point of the production-the semi-nude chorus-girl-was readily accepted in the world of Mexican entertainment as an emblem of modernity was in and of itself shocking.

Bataclanismo, the vast number of copycat theater productions, art, advertisements and media coverage in the wake of the show, Voilá La Bataclán, not only drastically altered daily performances and perceptions of gender and race, but also changed the way the city was imagined. As the phenomenon historically intersected with the rise of mass media and advertising (radio, photo journalism, fash-

107. This loosely translates as "The Most Beautiful Farm Flower." Ejidos, however, were rural communal landholdings associated with pre-Columbian notions of land ownership that featured heavily in revolutionary reform.

108. DDF, Memoria presentada al H. Congreso de la Union, September 1935-August 1936, p. 247. 
ion and mass marketing of beauty products), its grasp on society relied heavily on visual means. Deco bodies and the city were often intertwined in this barrage of visual materials that propagated a new beauty ideal for women, and illustrated that metropolitan modernity, even in its built environment, as mutually constitutive with the physical and behavioral aspects of a new femininity. If, as Peter Stallybrass and Allon White have suggested, identity formation is a process that centers on associations between place, class, and body, the Bataclán provided the vocabulary to articulate entirely new female subjectivities. ${ }^{109}$

Through new cultural forms in the 1920 s, in particular the rise of the mass media in particular, Mexico became increasingly connected with the outside world. Despite the nationalist and masculine nature of the institutionalized Revolution, modern ideas of how men and particularly women could behave pervaded revista theater, films, the lyrics of songs heard on the radio, and advertising in magazines. In the 1920s and in part the 1930s, these culture industries were for the most part in their infancy. Nonetheless, many urban women admired or made attempts to transform themselves into chicas modernas, ones who cut their braids, danced to new music, and seemed to defy the stereotypical abnegating wife and mother championed by state programs. ${ }^{110}$ Joanne Hershfield argues that through a Mexicanization of the transnational flapper, the chica moderna was able to both modernize a number of female roles available and to Mexican women in the 1920s and 1930s: working, exotic, and even domestic woman. ${ }^{11}$ I would add that it was through the vehicle of the Deco body, and its proposed universality, that these various types of femininity were able both to coexist and to map onto each other.

The desirability of the Deco body — white, thin, and tall-might have seemed to run counter to the aesthetics inherent in Indigenismo which revolutionary leaders embraced as the answer to forge a national culture that would be uniquely Mexican. Yet, while idealized indigenas linked to the countryside in didactic murals by Diego Rivera and David Alfaro Siquieros served to symbolize Mexico's unique and rich past, the Deco body of the modern metropolis reminded Indian and mestizo alike that being Mexican and modern was no longer so much about color as it was about form. Through the use of Deco bodies, indigenous and mestizo women could perform modernity as much as white women could perform Indigenismo. ${ }^{12}$ Hence, Indigenismo of the 1920 s was not as incompatible with

109. Peter Stallybras and Alon White, The Politics and Poetics of Transgression (London: Methuen, 1986), p. 25.

110. While not engaged in warfare of the global kind, Mexican society experienced a social revolution with a reformist agenda that created some new spaces in which women could exercise agency. By the mid-1930s, however, this window of opportunity gradually closed; despite large cross-class alliances, mobilization, and activism, women did not achicve either gender parity or the right to votc.

111. Hershfield, Imagining the Chica Moderna, p. 14.

112. On the performance of Indigenismo in portraiture, see Poole, “An Image of 'Our Indian."” 
modernity as much as the revolutionaries made it out to be. Unlike the denunciation of old nineteenth-century ideals of femininity, in part symbolized by the white powder, hour-glass divas, and frills of French Art Nouveau of the feminized Porfirian elite, the Deco body did not entail a rejection of color. Shaping Deco bodies was not a matter of color, of whitening in the strictest sense, but about engineering form. $L a$ Raza, used so often in revolutionary discourse as a standin for all inhabitants of the Mexican nation but referring largely to indigenous people, was invited to grow tall and slender, without the excess of historic circumstance weighing them down. Indias, too, were beautiful once they had lost their roundness and learned to wear heels, long and languid as the indigenas celebrated in muralism or the mestizaje of the india bonita. The Deco body thus facilitated the integration of indigenismo and mestizaje as discourses.

As bataclanismo invited Mexican women of all classes and ethnicities to embody the Deco aesthetic, freely move around the modern metropolis and engage in the daily performance of transgressing social and gender boundaries, such women took on the tenets of spectacle. According to Anne McClintock, as inversions of the traditional gender order expressed in dress, work, sex, and boundary crossings are not merely acts of resistance, but constitute ambiguous zones where women and men work out the tensions between social norms, fantasy, and desires. Tellingly, these dangerous zones need to be "secured" and transformed into spectacles through the exchange of money by paying women for their "performance." 113 Mexico City's spatial configuration of desire-Plaza Garibaldi, the carpas, the revista theaters, and the zones of prostitution - all had been secured by capitalist-endorsed spectacle. Women who drew on this spectacle in order to enact the lives they envisioned became, on the other hand, difficult to place.

Butler University

AgeEth SLuis

Indianapolis, Indiana

113. Anne McClintock, Imperial Leather: Race, Gender and Sexwality in the Colonial Contest (New York City: Routledge, 1995). 